\title{
Importance of Ghandhian Philosophy
}

\author{
Sheela Asopa* \\ Principal Govt. Senior Secondary School Dhawa, MA, Mphil, Bed, NET
}

*Corresponding Author: Sheela Asopa, Principal Govt. Senior Secondary School Dhawa, MA, Mphil, Bed, NET

\begin{abstract}
Gandhian ways and his ideals seem to be the only solution to overcome the present ever growing problem of terrorism which is leading the world to a doomsday. Gandhiji was leader of the past runs into the present and marches towards the future. He had always been a leader of the time ahead. No leader either today nor in future can match him with the charisma and calibre and wisdom that he had. At present political, economic, social and moral rights as well as values are going down and exploiting. In the course of development we have to think of these problems and try to find out the solutions best suited to our needs. The best suited solutions for the above problems of contemporary world is to follow Gandhi's principles. It is Gandhi's philosophy can save us from this predicament. Gandhi's profuse writings, speeches and talks cover every conceivable aspects of Indian life of his time as well as present world.
\end{abstract}

Keywords: doomsday, wisdom, contemporary, stomp, predicament

\section{INTRODUCTION}

We are in $21^{\text {st }}$ century which is commonly known as" The Century of development". Gandhian principles or value system is something that blend the entire India at one point of time. It initiate a revolution, that took the whole of nation in its stomp and lasted till we were able to get independence. This value system gave the nation the principles of truth, non-violence, satyagrah which result in people's heart. We are still alarm by the uniqueness of Gandhiji's principled approach. He endorsed simple living and high thinking while practising. At present political, economic, social and moral rights as well as values are going down and exploiting. In the course of development we have to think of these problems and try to find out the solutions best suited to our needs. The best suited solutions for the above problems of contemporary world is to follow Gandhi's principles. It is Gandhi's philosophy can save us from this predicament. Gandhi's profuse writings, speeches and talks cover every conceivable aspects of Indian life of his time as well as present world.

\section{Gandhian Philosophy}

Mahatma Gandhi is not merely a political philosopher, it is a message and philosophy of life. His mission was to reconstruct India from below upwards a decentralized socio-political and economic order with India's myriad villages as its base He was very much concerned with the nature, poor deprived and the downtrodden and he has intender to alter the evil, political, social, and economic system of the people. Gandhi is universally known as the most renowned theorist, philosopher and also the practitioner of truth, love, non-violence, tolerance freedom and peace. He was a leader of his people.

\section{THE MAIN PRINCIPLES /PHILOSOPHIES OF GANDHI ARE}

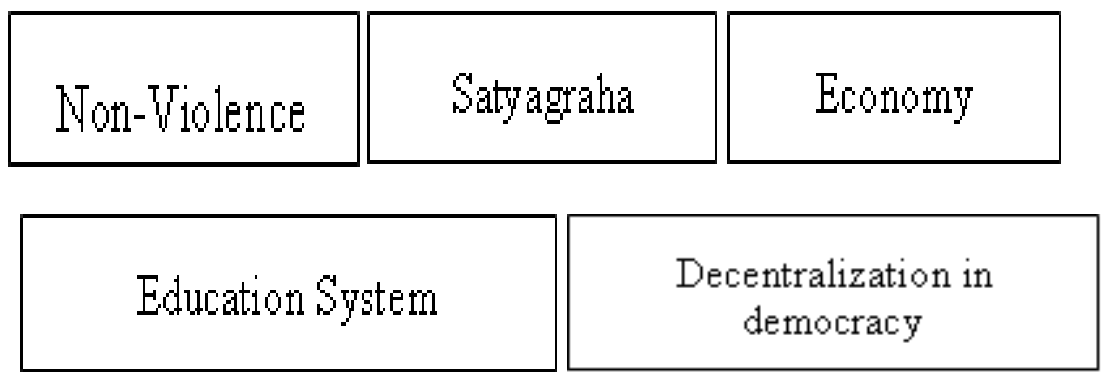




\subsection{Non -Violence}

Gandhiji said "Non-violence is the greatest force at the disposal of man-kind. It is mightier than the mightiest weapon of destruction devised by ingenuity of man". this is also need of today's scenario as terrorism is major threat all around the world and we has to raise voice The concept of nonviolence (ahimsa) and nonviolent resistance has a long history in Indian religious thought and has had many revivals in Christianity, Buddhist, Hinduism, Muslim, and Jain contexts. Gandhi explains his philosophy and way of life in his autobiography, The Story of My Experiments with Truth. He was quoted as saying:

"What difference does it make to the dead, the orphans, and the homeless, whether the mad destruction is wrought under the name of totalitarianism or the holy name of liberty and democracy?

"It has always been easier to destroy than to create".

Ahimsa, or non-violence, was another key tenet of Gandhi's beliefs. He held that total non-violence would rid a person of anger, obsession and destructive impulses for Non -Violence against the terrorism .Philosophy of non violence has great relevancy it contemporary 21 st century. In India most of the conflict and extremist revolutions already selected \& some are going to settle by non violence and peaceful means. Peace process in extremist movement, settlement of inter state conflict, Water dispute. For example: Cauvery water dispute, movement of Khalisthan in Punjab Mysore Maharashtra boundary conflict etc. According to the Gandhi non-violence does not mean meek submission to the will of the evil doer. It is the soul force or truth force. Non-violence is regarded has the highest law of human kind. It was the unique non-violent movement under his leadership that earned for India freedom from the colonial rule. In spearheading the campaign against the alien rule, Gandhiji adopted the innovative techniques of civil disobedience and social transformation, which had several exemplary features.

\subsection{Satyagraha}

Satyagraha is formed by two Sanskrit words Satya which have meaning Truth and Agraha have meaning holding firmly. The term was famous and popular during the Indian Independence Movement

The central concepts of Gandhi's philosophy is 'Satyagraha' The pivotal and defining element of Gandhism is satya, it is a Sanskrit word for truth. It also refers to a virtue in Indian religions, referring to being truthful in one's thought, speech and action. Satya is also called as truth. It is itself a whole philosophy of non violenvence. A Satygraha campaign is undertaken only after all other peaceful means have proven ineffective. An attempt is made to convert, perused the opponent. A Satyagraha campaign is undertaken only after all other peaceful means have proven ineffective. At its heart is non -violence. An attempt is made to convert, persuade or win over the opponent.

Gandhi said: "The Truth is far more powerful than any weapon of mass destruction.

The purpose of Satyagrah is to fight against injustice and tyranny. Satyagrahi should have moral force; he makes understand by means of reason. There is no place for physical force.

In Gandhi views satyagrah as most powerful weapon and he suggested some important methods. They are:

- Strike

- Fasting

- Non- cooperation

This satyagrah philosophy is still relevant and are followed not only in India but also followed all over the world. In Indian context, principle of Satyagrah still holds good. Example are many peaceful protest in the form of candle march almost all over the country for many issues. India's foreign policy is also based on peaceful co-existence and it is reflected in not indulging in aggression first though India remains prepared as the security threats accumulate.

\section{GANDhi's ECONOMY PHILOSOPHY}

Mahatma gandhi had his own approach to the economic problem of India. He did not essentially believe in prompting large scale industrialization 
Gandhi espoused an economic theory of simple living and self-sufficiency/import substitution, rather than generating exports. He envisioned a more agrarian India upon independence that would focus on meeting the material needs of its citizenry prior to generating wealth and industrialising. ${ }^{[16]}$

Gandhi also adopted Khadi the clothing style of most Indians in the early 20th century. His adoption of khadi, or homespun cloth, was intended to help small scale industries and to eradicate the evils of poverty, social and economic discrimination. It was also aimed as a challenge to the contrast that he saw between most Indians, who were poor and traditional, and the richer classes of educated, liberalminded Indians who had adopted Western mannerisms, clothing and practices.

The clothing policy was designed to protest against British economic policies in India. Millions of poor Indian workers were unemployed and entrenched in poverty, which Gandhi linked to the industrialisation of cotton processing in Britain. Gandhi promoted khadi as a direct boycott of the Lancashire cotton industry, linking British imperialism to Indian poverty. $\mathrm{He}$ focused on persuading all members of the Indian National Congress to spend some time each day hand-spinning on the charkha (spinning wheel). In addition to its point as an economic campaign, the drive for handspinning was an attempt to connect the privileged Indian brahmins and lawyers of Congress to connect with the mass of Indian peasantry.

Many prominent figures of the Indian independence movement, including Motilal Nehru, were persuaded by Gandhi to renounce their smart London-made clothes in favour of khadi.

Gandhian economy still relevant to our time. He was not against machinery as such. He was afraid that use of machinery on large scale would result in technological unemployment. He extend Ruskin's concepts of the equality of wages to all kinds of labour and equal distribution. The mad race in industrialization and urbanization has resulted in pollution of environment and Gandhi abundant of luxurious life.

In India, economic development has been mostly confined to the urban conglomerates. In the process, the rural India that comprises 700 million people has been given short shrift. Gandhiji's philosophy of inclusive growth is fundamental to the building of a resurgent rural India. He believed in "production by the masses" rather than in mass production, a distinctive feature of the industrial revolution. It is surprising, even paradoxical, that these days Gandhian philosophy should find increasing expression through the most modern technology! Now, it is possible to establish small-scale and medium-scale factories in smaller towns and remote corners of the country, thanks to the phenomenal innovations in communication and information technologies. New technologies have brought in widespread and lowcost electronic connectivity that enables instantaneous contact between industrial units and the sellers and consumers of their products. Location and logistics are no more a limitation or constraint for industrial development.

\section{EDUCATION SYSTEM}

Education system proposed by Gandhi is called as "Basic Education". He mainly aims at the education in mother tongue an education should be make the children skilled and independent. More than ever before, Gandhiji's teachings are valid today, when people are trying to find solutions to the rampant greed, widespread violence, and runaway consumptive style of living. Education through medium of the strange tongue breaks the concordance which should exits by mother tongue. Foreign languages made the kids crammers and immitators, unfit for original work and thought. Gandhi said 'literacy in itself no education'. I would prefer the child education by teaching it a useful handicraft. It purpatuates in radical restructuring of the sociology of school knowledge in India in which the "Literacy of the lower castes" such as spinning, weaving, leather work, book binding etc would be made central.

Gandhi's educational system has got the minimum attention. It aims all-round development of human personality. for Gandhi, the true development of head, heart and soul are necessary for a satisfactory system of education. Gandhi wanted to construct small, self reliant communities with is ideal citizens being all industrious, self respecting and generous individual living in a small co-operative community. Gandhiji said that The school must be an extension of home there must be concordance between the impressions which a child gathers at home and at school, if the best results are to be obtained. Education through the medium of strange tongue breaks the concordance which should exist. Those who breaks this relationship are enemies of the people even though their motives may be 
honest. To be a voluntary victim of this system of education is as good as the betrayal of our duty towards our mothers. The harm done by this alien type of education does not stop here; it goes much further. It has produced a gulf between the educated classes and the masses. The people look on us as beings apart from them.

\section{GANDHIAN DECENTRALIZATION IN DEMOCRACY PHILOSOPHY}

Gandhiji stood for the decentralization of both political and economic power which he believed is possible only by beginning from bottom upwards and not vice-versa. Village Swaraj was an essential componet of decentralized polity or decentralized governance. Swaraj is the best form of governance. It cannot be established by a few people sitiing at the top but by sharing authority with the people. Gandhiji envisaged an ideal political order in which everybody is his own ruler and he rules himself in such a way that he is never a hindrance to other. Swaraj of Gandhiji's dream is the poor man's swaraj. It also meant Poorna Swarj or complete independence. It signifies that the masses should become conscious of their capacity to regulate and control authority when it goes astray. It is not the government of the omnipotent state but the government of the people, by the people and for the people. It is democracy of the highest order for its guiding principle is equality and justice. Real Swaraj comes only by individual initiative and by one's own effort. What others have done for me is not home-rule but foreign rule. Self-rule even if it is leads to anarchy is better than orderly 4 foreign rule. Gandhiji preferred self-rule over and above all forms of government. Gandhiji conceived true democracy along non-violent lines in which non-violence becomes a creed, an article of faith rather than a matter of mere policy. Gandhiji believed that, true democracy is an outcome of un-adulterated non-violence. That government alone can be considered best which governs the largest number of happy and virtuous individuals. True democracy or the Swaraj of the masses can never come through non-violent and untruthful means. For democracy and violence seldom go together. In the non-violent democracy of Gandhiji's conception, the basic unit is the villages which will always be abide by the ideals of truth and non-violence. Every village is a self sufficient republic or panchayat.

The government of the village will be the panchayat of five persons annually elected by the adult villagers both male and female. It is considered as the unit of local-self government. It is the original custodian of all authority. The panchayat system as viewed by Gandhiji represents a village community. It is an autonomous Indian political institution as far as the internal village administration is concerned. Panchayat Raj means a political structure with its base at the village level with 5 legislative, executive and judiciary powers. Gandhiji had evolved a three-tier system of Panchayat Raj linking up the village Panchayat with the Block and District levels. In Panchayat Raj system envisaged by Gandhiji, people's independence begins from the village level. In true democracy it is the individual who is the unit. In true democracy of Gandhiji's dream the humblest and the lowest Indian is equally the ruler of India with the tallest in the country. The individual has complete freedom to manage his own affairs. The spirit of non-violence coupled with individual freedom and equality provide the solid foundation for Gandhiji's concept of decentralization in the political sphere. Gandhiji's vision of rebuilding free India was a corollary to his larger vision to end exploitation and construction of a 'Just' social order with equality prevailing in every sphere of human life. In his conception of Sarvodaya social order, Gandhiji has assigned importance to economics founded on ethics. Economics, for Gandhiji, is a normative science. The moral economics of Gandhiji is essentially humanized and welfare oriented. True economics never militates against human welfare. Gandhiji's non-violent economy was a panacea for most of the economic ills. Gandhiji was in the look out for an 6 indigenous economy model based on agriculture. He was for an agrarian non-violent rural economy order, in which there is no scope for exploitation and competitions of man by man. He favoured decentralization in the economic field as well. Gandhiji's non-violent economy model stood for production by the masses rather than mass production. He had dreamt of an ideal economic order based on indigenous culture and civilization and hence became a trenchant critic of western civilization, mechanization and industrialization. He pleaded for simplicity and reduction of wants rather than its multiplication. He pleaded for the use of less machinery and stressed the ideal of manual labour. Mechanized economy model is no longer a valid model for India for the individual will be a slave to machinery. What Gandhiji objected was not machinery as such but the craze for machinery. Economic decentralization is related to rural economy and cottage industries located in the rural areas. True democracy and true economics are essentially mancentred. It is not meant for a select few but for all with a view to empower them in the different spheres of life. He gave utmost 
importance to the freedom of the individual. The individual is nucleus around which revolve the other institutions.

Gandhi wanted political power to be distributed among the villages in India. He preferred the term 'swaraj' to describe what he called true democracy. That democracy based upon freedom. He calls panchayathi raj or village swaraj. According to Gandhi Decentralization of political power is the basic requirement for the success of true democracy. For him a decentralized democracy based on villages in which voluntary co-operation in the condition of dignified and peaceful existence. Gandhian Democracy is still relevant in India. It is clear from the 73rd and 74th constitutional amendments of Indian constitution that is related only with rural administration of India. One significant provision of this amendments is decentralization of power upto the rural level. It has already been implemented in India in 1992.

\section{Conclusions}

To conclude, we can say that most of the teachings of Mahatma Gandhi hold relevance even in today's world Gandhian philosophy is not only simultaneously political, moral and religious, it is also traditional and modern simple and complex. The path shown or followed by Gandhiji at that time still remains a very valid one if somebody chooses to tread on it. His relevance in different fields is unquestionable unchallengeable. For the very survival of human being, it is a imperative on our part to an act open his advice because only on his relevance, In today's scenario, 'Eye for an Eye' is no solution as it only aggravates the situation. Peaceful coexistence, economic independence, respect for women, child centred education and basic education for every one, universal brotherhood-all these principles should serve as a beacon of light to guide humanity of a better world we shall survive together or if we fail in our venture, we are bound to perish together. Gandhian ways and his ideals seem to be the only solution to overcome the present ever growing problem of terrorism which is leading the world to a doomsday. Gandhiji was leader of the past runs into the present and marches towards the future. He had always been a leader of the time ahead. No leader either today nor in future can match him with the charisma and calibre and wisdom that he had.

\section{REFERENCES}

[1] Brechet .A - Political Theory

[2] Diraj Kr. Das- Relavance of Gandhian Philosophy.

[3] Radhakrishnan S - Mahathma gandhi -Essays and Relections

[4] V.P. Varma - Political Philosophy of Gandhi and Sarvodaya

[5] The Hindu- Relevance of Mahatma Gandhi December 7, 2010

[6] Relevance of Gandhian Philosophy in the 21st century, ANANTH KUMAR. D. R.

Citation: Sheela Asopa. "Importance of Ghandhian Philosophy" International Journal of Political Science (IJPS), vol 5, no.3, 2019, pp. 44-48 doi: http://dx.doi.org/ 10.20431/2454-9452.0503003.

Copyright: (c) 2019 Authors. This is an open-access article distributed under the terms of the Creative Commons Attribution License, which permits unrestricted use, distribution, and reproduction in any medium, provided the original author and source are credited. 